\title{
ON YOUNG'S INEQUALITY AND ITS REVERSE FOR BOUNDING THE LORENZ CURVE AND GINI MEAN
}

\author{
Pietro CERone
}

Abstract. The performance of the Young integral inequality is investigated for bounding the Lorenz curve and the Gini index. The study relies on a comparison of reverse Young type integral inequalities. The resulting approximation and bounds for the Lorenz curve and the Gini index are compared with previous results.

Mathematics subject classification (2000): 62H20, 62G10, 62P20, $26 \mathrm{D} 15$.

Keywords and phrases: Gini mean difference, Gini index, Lorenz curve, variance, coefficient of variation, Young's integral inequality, reverse Young's inequality.

\section{REFERENCES}

[1] P.S. Bullen, The inequality of Young, Univ. Beograd. Publ. Elektrotehn. Fak. Ser. Mat. Fiz., 357-380 (1971), 51-54.

[2] P. CERONE, Bounding the Gini mean difference, Inequalities and Applications, International Series of Numerical Mathematics, Vol. 157, C. Bandle, A. Losonczi, Zs. Pales and M. Plum, Eds., 2009, 77-89.

[3] P. Cerone And S.S. Dragomir, A survey on bounds for the Gini Mean Difference, Advances in Inequalities from Probability Theory and Statistics, N.S. Barnett and S.S. Dragomir (Eds.), Nova Science Publishers, 2008, 81-111.

[4] P. Cerone And S.S. Dragomir, Bounds for the Gini mean difference via the Sonin identity, Comp. Math. Modelling, 50 (2005), 599-609.

[5] P. Cerone And S.S. Dragomir, Bounds for the Gini mean difference via the Korkine identity, J. Appl. Math. \& Computing (Korea), 22, 3 (2006), 305-315.

[6] P. Cerone And S.S. Dragomir, Bounds for the Gini mean difference of continuous distributions defined on finite intervals (I), Applied Mathematics Letters, 20 (2007), 782-789.

[7] P. CERone AND S.S. Dragomir, Bounds for the Gini mean difference of continuous distributions defined on finite intervals (II), Comput. Math. Appl., 52, 10-11 (2006), 1555-1562.

[8] H.A. DAVID, Gini's mean difference rediscovered, Biometrika, 55 (1968), 573.

[9] J.B. Diaz And F.T. MetCalf, An analytic proof of Young's inequality, Amer. Math. Monthly, 77 (1970), 603-609.

[10] J.L. Gastwirth, The estimation of the Lorentz curve and Gini index, Rev. Econom. Statist., 54 (1972), 305-316.

[11] C. GINI, Variabilità e Metabilità, contributo allo studia della distribuzioni e relationi statistiche, Studi Economica-Gicenitrici dell' Univ. di Coglani, 3 (1912), art. 2, 1-158.

[12] G.M. GiongI, Bibliographic portrait of the Gini concentration ratio, Metron, XLVIII, 1-4 (1990), $103-221$.

[13] G.M. Giongi, Alcune considerazioni teoriche su di un vecchio ma per sempre attuale indice: il rapporto di concentrazione del Gini, Metron, XLII, 3-4 (1984), 25-40.

[14] G.H. Hardy, J.E. LitTlewood and G. Polya, Inequalities, Cambridge Univ. Press.

[15] M. Kendall and A. Stuart, The Advanced Theory of Statistics, Volume 1, Distribution Theory, Fourth Edition, Charles Griffin \& Comp. Ltd., London, 1977.

[16] P.R. Mercer, Extensions of Steffensen's inequality, J. Math. Anal. \& Applics., 246 (2000), 325-329.

[17] M.J. Merkle, A contribution to Young's inequality, Univ. Beograd. Publ. Elektrotehn. Fak. Ser. Mat. Fiz, 461-697 (1974), 265-267. 
[18] D.S. Mitrinović, J.E. PeČArić And A.M. Fink, Classical and New Inequalities in Analysis, Kluwer Academic Publishers, Dordrecht/Boston/London, 1993.

[19] Z. PÁLES, A general version of Young's inequality, Arch. Math., 58 (1992), 360-365.

[20] A. WitkowsKi, On Young's inequality, J. Ineq. Pure and Appl. Math., 7, 5 (2007), Art. 164. [ONLINE http: //jipam.vu.edu . au/article.php?sid=782].

[21] W.H. Young, On classes of summable functions and their Fourier series, Proc. Roy. Soc. London (A), 87 (1912), 225-229. 